\title{
Modeling the effects of tree species and incubation temperature on soil's extracellular enzyme activity in 78-year-old tree plantations
}

\author{
Xiaoqi Zhou ${ }^{1,2, *}$, Shen S. J. Wang ${ }^{3, *}$, and Chengrong Chen ${ }^{2}$ \\ ${ }^{1}$ Tiantong National Station for Forest Ecosystem Research, Center for Global Change and Ecological Forecasting, Shanghai \\ Key Lab for Urban Ecological Processes and Eco-restoration, School of Ecological and Environmental Sciences, East China \\ Normal University, Shanghai 200241, China \\ ${ }^{2}$ Australian Rivers Institute and Griffith School of Environment, Griffith University, Nathan, Brisbane 4111, \\ Queensland, Australia \\ ${ }^{3}$ Machine Learning Systems, Computing and Information Systems, The University of Melbourne, Melbourne 3010, Australia \\ *These authors contributed equally to this work.
}

Correspondence to: Xiaoqi Zhou (xqzhou@des.ecnu.edu.cn) and Chengrong Chen (c.chen@griffith.edu.au)

Received: 17 April 2017 - Discussion started: 31 May 2017

Revised: 24 October 2017 - Accepted: 24 October 2017 - Published: 1 December 2017

\begin{abstract}
Forest plantations have been widely used as an effective measure for increasing soil carbon (C), and nitrogen $(\mathrm{N})$ stocks and soil enzyme activities play a key role in soil $\mathrm{C}$ and $\mathrm{N}$ losses during decomposition of soil organic matter. However, few studies have been carried out to elucidate the mechanisms behind the differences in soil $\mathrm{C}$ and $\mathrm{N}$ cycling by different tree species in response to climate warming. Here, we measured the responses of soil's extracellular enzyme activity (EEA) to a gradient of temperatures using incubation methods in 78-year-old forest plantations with different tree species. Based on a soil enzyme kinetics model, we established a new statistical model to investigate the effects of temperature and tree species on soil EEA. In addition, we established a tree species-enzyme- $\mathrm{C} / \mathrm{N}$ model to investigate how temperature and tree species influence soil $\mathrm{C} / \mathrm{N}$ contents over time without considering plant $\mathrm{C}$ inputs. These extracellular enzymes included $\mathrm{C}$ acquisition enzymes ( $\beta$-glucosidase, BG), $\mathrm{N}$ acquisition enzymes $(N$ acetylglucosaminidase, NAG; leucine aminopeptidase, LAP) and phosphorus acquisition enzymes (acid phosphatases). The results showed that incubation temperature and tree species significantly influenced all soil EEA and Eucalyptus had 1.01-2.86 times higher soil EEA than coniferous tree species. Modeling showed that Eucalyptus had larger soil C losses but had 0.99-2.38 times longer soil $\mathrm{C}$ residence time than the coniferous tree species over time. The differences in the residual soil $\mathrm{C}$ and $\mathrm{N}$ contents between Eucalyptus and
\end{abstract}

coniferous tree species, as well as between slash pine ( $\mathrm{Pi}$ nus elliottii Engelm. var. elliottii) and hoop pine (Araucaria cunninghamii Ait.), increase with time. On the other hand, the modeling results help explain why exotic slash pine can grow faster, as it has 1.22-1.38 times longer residual soil $\mathrm{N}$ residence time for LAP, which mediate soil $\mathrm{N}$ cycling in the long term, than native coniferous tree species like hoop pine and kauri pine (Agathis robusta $\mathrm{C}$. Moore). Our results will be helpful for understanding the mechanisms of soil $\mathrm{C}$ and $\mathrm{N}$ cycling by different tree species, which will have implications for forest management.

\section{Introduction}

Global mean temperature is predicted to increase by 1.8 $4.0^{\circ} \mathrm{C}$ by the end of this century as a result of anthropogenic activities that increase carbon dioxide $\left(\mathrm{CO}_{2}\right)$ in the atmosphere (IPCC, 2013). Soil stocks large amounts of carbon (C) in terrestrial ecosystems, at least 4 times greater than that of the global stocks of $\mathrm{C}$ in the atmosphere and living plants (Jobbágy and Jackson, 2000). In the context of climate warming, minor losses of $\mathrm{C}$ via decomposition of soil organic matter (SOM) can cause positive feedback to atmospheric $\mathrm{CO}_{2}$ concentrations and global temperature (IPCC, 2013), resulting in an increase in plant growth and decomposition of SOM 
(Davidson and Janssens, 2006; Wu et al., 2011), which can profoundly alter soil C and nitrogen (N) cycling (Luo, 2007).

Establishing forest plantations has been accepted as an effective measure for increasing soil $\mathrm{C}$ stocks and mitigating atmospheric $\mathrm{CO}_{2}$ in national budgets (Vesterdal et al., 2013). Afforestation with different tree species has been found to enhance soil C stocks (Berthrong et al., 2009), with large differences in soil $\mathrm{C}$ sequestration under different tree species (Vesterdal et al., 2013). Until now, however, the underlying mechanisms behind the differences in soil $\mathrm{C}$ and $\mathrm{N}$ contents under different tree species have remained unclear (Hobbie, 2015). Alongside $\mathrm{C}$ and $\mathrm{N}$ inputs via litter decomposition and root exudation by different tree species, $\mathrm{C}$ and $\mathrm{N}$ losses via SOM decomposition are important for soil $\mathrm{C}$ and $\mathrm{N}$ cycling. During the decomposition of SOM, soil's extracellular enzyme activities (EEA) represent the rate limiting step of decomposition, marking the conversion of SOM into dissolved organic $\mathrm{C}$ and $\mathrm{N}$, which is then metabolized by microbial decomposers (Schimel and Bennett, 2004; Caldwell, 2005; Bengtson and Bengtsson, 2007; Conant et al., 2011). Given the importance of soil EEA, a soil $\mathrm{C} / \mathrm{N}$ model that incorporates soil EEA is a useful measure for investigating the effect of tree species on soil $\mathrm{C}$ and $\mathrm{N}$ cycling, which may improve our understanding of the mechanisms underlying differences in soil $\mathrm{C}$ and $\mathrm{N}$ contents under different tree species.

Previous work has shown that in a variety of ecosystems, the enzymatic activities associated with decomposition differ, depending upon the quality of SOM such as soil $\mathrm{C}: \mathrm{N}$ ratios (Sinsabaugh et al., 2002). Forest plantations with different tree species have been reported to have large differences in the quantity and quality of SOM, thus greatly influencing soil EEA (Lovett et al., 2004; Lu et al., 2012; Hobbie, 2015). Generally, as soil EEA increases with increasing temperature (Koch et al., 2007), to get a certain amount of substrate via decomposition of SOM, microbes in warmer soils need to produce fewer extracellular enzymes that are involved in $\mathrm{C}$ and nutrient cycling (Allison, 2005). However, there are only a handful of studies that have measured the responses of soil's EEA to warming under different tree species (Allison et al., 2010; Kardol et al., 2010). To predict how soil C and $\mathrm{N}$ contents are likely to respond to warming as a future climate scenario under different tree species, it is necessary to establish a new soil-enzyme- $\mathrm{C} / \mathrm{N}$ model that includes incubation temperature to investigate the effects of warming on soil $\mathrm{C}$ and $\mathrm{N}$ dynamics.

Current soil organic $\mathrm{C}$ models can reproduce changes in $\mathrm{C}$ dynamics on various scales under most conditions (ToddBrown et al., 2013). However, this is not the case in highly variable environments, which may require more models that are mechanistic and that include enzyme activities (Lawrence et al., 2009; Allison et al., 2010; Li et al., 2010). A few studies have explicitly incorporated enzyme activity into their models and these models have proven to be powerful tools for investigating changes in soil $\mathrm{C}$ and $\mathrm{N}$ contents in response to warming, as temperature directly affects soil EEA (Shimel and Weintraub, 2003; Lawrence et al., 2009; Davidson et al., 2012). Here, we selected a long-term tree plantation that was established on a former banana (Musa acuminata Colla) farm in subtropical Australia. As these tree plantations were developed from the same soil material, we assume that the current differences in soil properties and litter $\mathrm{C} / \mathrm{N}$ contents are a "black box" and are mainly derived from the effects of tree species. We therefore simplified the soil-enzyme-C/N model to consider the effects of both tree species and incubation temperature, although we acknowledge that soil properties such as $\mathrm{pH}$ and soil moisture content are important factors influencing soil EEA (Caldwell, 2005; Allison et al., 2010; Kardol et al., 2010). On the other hand, the enzymatic performance of microbial communities from different tree plantations was explored in a short-term incubation experiment along a laboratory temperature gradient.

We established a new tree species-enzyme- $\mathrm{C} / \mathrm{N}$ model without considering soil $\mathrm{C}$ inputs. The objective of this study was to investigate (1) changes in residual soil $\mathrm{C}$ and $\mathrm{N}$ contents under different tree species with time and their responses to different temperatures and (2) differences in residual soil $\mathrm{C}$ and $\mathrm{N}$ contents between tree species with time in a 78-year-old forest plantation in subtropical Australia by combining soil EEA assays and a model of the effects of tree species on soil EEA in response to a gradient of incubation temperatures. We hypothesized that long-term tree plantations would change the quality of SOM, thus greatly affecting soil EEA.

\section{Materials and methods}

\subsection{Experimental site}

We selected a 78-year-old forest plantation with different tree species that was established in 1935 on a site that was originally a banana farm. The forest plantation site is located at Cooloola, Tin Can Bay, southeast Queensland, Australia $\left(25^{\circ} 56^{\prime} 49^{\prime \prime} \mathrm{S}, 153^{\circ} 5^{\prime} 27^{\prime \prime} \mathrm{E}\right)$. The altitude is $43 \mathrm{ma}$ a.s.1. with a mean annual rainfall of $1287 \mathrm{~mm}$. Winter temperatures range from 7 to $23^{\circ} \mathrm{C}$ over June to August and summer temperatures range from 18 to $30^{\circ} \mathrm{C}$ over December to February (Lu et al., 2012). Four tree species were selected, including an exotic coniferous species (slash pine (Pinus elliottii Engelm. var. elliottii)) and two native species of conifer (hoop pine (Araucaria cunninghamii Ait)) and kauri pine (Agathis robusta C. Moore), as well as a Eucalyptus species (Eucalyptus grandis W. Hill ex Maiden). All of them were planted adjacently on a broad, gently undulating plain with a gentle slope of less than $5^{\circ}$. The plot size of each tree species was $1.087,0.308,0.428$ and 0.60 ha, respectively (Lu et al., 2012). Four subplots of $10 \mathrm{~m} \times 20 \mathrm{~m}$ in each tree plantation were randomly selected for soil sampling, resulting in a total of 16 subplots. The thicknesses of the litter and fermentation layers were 5-6 and 1-2 cm for slash pine, respectively, 
whereas the corresponding values were $4-5$ and $1-2 \mathrm{~cm}$ for the hoop pine and kauri pine plots. The Eucalyptus plot had a thicker litter layer of $8-10 \mathrm{~cm}$ and a similarly thick fermentation layer of $1-2 \mathrm{~cm}$.

\subsection{Soil sampling and measurement of soil physicochemical properties}

Soil samples were collected in August 2013 following a diagonal sampling pattern (i.e., one point at each corner and one in the center of each plot) using a soil auger $(8 \mathrm{~cm}$ in diameter) at $0-10 \mathrm{~cm}$ depth within each plot. The soil cores were immediately mixed thoroughly and kept in a cooler $\left(4^{\circ} \mathrm{C}\right)$. After passing the samples through a $2 \mathrm{~mm}$ sieve to remove roots and stones, the soil samples were stored at $4{ }^{\circ} \mathrm{C}$ prior to analysis. Part of each fresh sample was stored at $4{ }^{\circ} \mathrm{C}$ for analysis of soil moisture, $\mathrm{pH}$, and extractable organic $\mathrm{C}$ (EOC) and N (EON) (Zhou et al., 2017). The other parts were air-dried and stored at room temperature for soil soluble organic $\mathrm{C}$ and $\mathrm{N}$ analysis using hot water extraction, and for soil total $\mathrm{C}$ and $\mathrm{N}$ analysis after being finely ground. Soil moisture content was determined after samples were ovendried at $105^{\circ} \mathrm{C}$ overnight. The particle size of these soils was dominated by the sand fraction $(\sim 96 \%)$. All soil biochemical properties are shown in Table 1.

\subsection{Measurements of soil enzyme activities}

The activity of extracellular enzymes involved in $\mathrm{C}, \mathrm{N}$ and phosphorus $(\mathrm{P})$ cycling was measured. These enzymes included $\mathrm{C}$ acquisition enzymes ( $\beta$-glucosidase, BG), $\mathrm{N}$ acquisition enzymes ( $N$-acetylglucosaminidase, NAG; leucine aminopeptidase, LAP) and $\mathrm{P}$ acquisition enzymes (acid phosphatases). BG catalyzes one of the steps of cellulose degradation, NAG is involved in chitin and fungal cell wall breakdown, LAP breaks down the polypeptides involved in the mineralization of $\mathrm{N}$ from the substrates with polypeptides, and phosphatase is involved in the release of inorganic P. Enzyme activities were assayed spectrophotometrically using para-nitrophenol-linked substrates (Verchot and Borelli, 2005; Sinsabaugh et al., 2009; Zhou et al., 2013). Briefly, moist field soil $(1 \mathrm{~g})$ was suspended in $4 \mathrm{~mL}$ of a $0.05 \mathrm{molL}^{-1}$ sodium acetate buffer $(\mathrm{pH} 6.5$ for acid phosphatase, $\mathrm{pH} 5.0$ for all other enzymes). After the substrates $(1 \mathrm{~mL})$ were added to Erlenmeyer flasks with the soil solution, the flasks were incubated in the dark at a gradient of temperatures $\left(4,15,20,25,30\right.$ and $\left.37^{\circ} \mathrm{C}\right)$. The duration of incubation depended upon the optimal temperature for each enzyme: $1 \mathrm{~h}$ for BG and acid phosphatase, $3 \mathrm{~h}$ for NAG and $5 \mathrm{~h}$ for LAP at $20,25,30$ and $37^{\circ} \mathrm{C}$, but $1.5 \mathrm{~h}$ for BG and $5 \mathrm{~h}$ for NAG and $8 \mathrm{~h}$ for LAP at $4{ }^{\circ} \mathrm{C}$ and $15^{\circ} \mathrm{C}$. After incubation, $1 \mathrm{M} \mathrm{NaOH}(4 \mathrm{~mL})$ was added to quench the reaction in the flasks. Enzyme activities were expressed as milligrams of para-nitrophenol formed per gram of dry soil per hour.

\subsection{Modeling and statistical analyses}

We assumed that the differences in soil properties and litter $\mathrm{C} / \mathrm{N}$ contents under different tree species are the results of effects of tree species, and therefore we established a new soil-enzyme- $\mathrm{C} / \mathrm{N}$ model to consider the effects of both tree species and incubation temperature without considering other soil properties and litter $\mathrm{C}$ inputs derived from tree species. In other words, we considered changes in soil properties and $\mathrm{C}$ inputs to be a "black box" as part of the overall effects of tree species, all of which influenced soil EEA.

We first transformed the enzyme activity data using a natural logarithm. As the enzyme activity data for each plot were not independent along a gradient of temperatures, we needed to consider the interaction of tree species and incubation temperature on soil EEA. So we established a tree species-enzyme model, Model 1, to investigate the effects of tree species, incubation temperature and their interaction on soil EEA. Model 1 is as follows:

$$
\begin{aligned}
& \mathrm{EEA}_{\mathrm{it}}= \\
& \exp \left\{\beta_{0}+\left(\beta_{1}+X_{1 \mathrm{it}} \times \beta_{1 \mathrm{sp}}+X_{2 \mathrm{it}} \times \beta_{1 \mathrm{hp}}+X_{3 \mathrm{it}} \times \beta_{1 \mathrm{kp}}\right) \times T\right. \\
& \left.+\left(X_{1 \mathrm{it}} \times \beta_{2 \mathrm{sp}}+X_{2 \mathrm{it}} \times \beta_{2 \mathrm{hp}}+X_{3 \mathrm{it}} \times \beta_{2 \mathrm{kp}}\right)+\varepsilon_{\mathrm{it}}\right\} \\
& X_{1 \mathrm{it}}=\left\{\begin{array}{l}
1 \text { if the } i \text { th tree is slash pine, } \\
0 \text { otherwise, }
\end{array}\right. \\
& X_{2 \mathrm{it}}=\left\{\begin{array}{l}
1 \text { if the } i \text { th tree is hoop pine, } \\
0 \text { otherwise, }
\end{array}\right. \\
& X_{3 \mathrm{it}}=\left\{\begin{array}{l}
1 \text { if the } i \text { th tree is kauri pine, } \\
0 \text { otherwise },
\end{array}\right.
\end{aligned}
$$

where $\mathrm{EEA}_{\mathrm{it}}$ indicates the soil's extracellular enzyme activity; $i=1,2, \ldots, 16$ is the plot number; $T$ is the temperature $\left(4,15,20,25,30\right.$ and $\left.37^{\circ} \mathrm{C}\right) ; X_{1 \mathrm{it}}, X_{2 \mathrm{it}}$ and $X_{3 \mathrm{it}}$ indicate the effects of tree species; $\beta_{0}$ is a constant; $\beta_{1}$ is the temperature coefficient; $\beta_{1 \mathrm{sp}}, \beta_{1 \mathrm{hp}}, \beta_{1 \mathrm{kp}}, \beta_{2 \mathrm{sp}}, \beta_{2 \mathrm{hp}}$ and $\beta_{2 \mathrm{kp}}$ are the slash pine, hoop pine and kauri pine coefficients, respectively, with temperature and without temperature; and $\varepsilon_{\text {it }}$ is the normal distribution with a 0 mean and $\sigma_{\varepsilon}^{2}$ variance. We ran all these enzyme activity data in Model 1 and the $F$ test results of the effects of temperature and tree species on soil EEA are presented Table S1.

We found that the interactions between incubation temperature and tree species were not significant on soil EEA (Table S1). Therefore, based on Model 1, we further established a simpler model (Model 2) without considering their interactions. We also ran a comparison of performance of Model 1 and Model 2 using the Akaike information criterion and the Bayesian information criterion (Table S2). Both results show that the performance of Model 2 is better than Model 1, we 
Table 1. Soil biochemical properties in 78-year-old forest plantations with different tree species.

\begin{tabular}{lllll}
\hline Properties & Slash pine & Hoop pine & Kauri pine & Eucalyptus \\
\hline Moisture $(\%)$ & $4.26 \pm 0.22 \mathrm{~b}$ & $3.11 \pm 0.53 \mathrm{~b}$ & $3.09 \pm 0.67 \mathrm{~b}$ & $7.69 \pm 1.66 \mathrm{a}$ \\
$\mathrm{pH}$ & $4.58 \pm 0.03 \mathrm{~b}$ & $5.64 \pm 0.22 \mathrm{a}$ & $6.01 \pm 0.23 \mathrm{a}$ & $4.49 \pm 0.04 \mathrm{~b}$ \\
Total C $\left(\mathrm{Mg} \mathrm{ha}^{-1}\right)$ & $7.36 \pm 0.57 \mathrm{~b}$ & $5.69 \pm 0.73 \mathrm{~b}$ & $5.07 \pm 0.75 \mathrm{~b}$ & $13.88 \pm 2.22 \mathrm{a}$ \\
Total N $\left(\mathrm{kg} \mathrm{ha}^{-1}\right)$ & $232 \pm 22 \mathrm{~b}$ & $245 \pm 23 \mathrm{~b}$ & $239 \pm 33 \mathrm{~b}$ & $462 \pm 71 \mathrm{a}$ \\
$\mathrm{C}: \mathrm{N}$ & $31.8 \pm 0.7 \mathrm{a}$ & $23.1 \pm 1.3 \mathrm{~b}$ & $21.2 \pm 0.7 \mathrm{~b}$ & $29.8 \pm 0.6 \mathrm{a}$ \\
EOC $\left(\mathrm{mg} \mathrm{kg}^{-1}\right)$ & $340 \pm 41 \mathrm{~b}$ & $341 \pm 31 \mathrm{~b}$ & $360 \pm 30 \mathrm{~b}$ & $625 \pm 77 \mathrm{a}$ \\
EON $\left(\mathrm{mg} \mathrm{kg}^{-1}\right)$ & $14.7 \pm 2.9 \mathrm{~b}$ & $18.4 \pm 1.9 \mathrm{ab}$ & $23.1 \pm 1.5 \mathrm{a}$ & $22.4 \pm 1.8 \mathrm{a}$ \\
EOC $:$ EON & $24.17 \pm 1.81 \mathrm{a}$ & $18.79 \pm 1.48 \mathrm{~b}$ & $15.66 \pm 0.87 \mathrm{~b}$ & $27.64 \pm 1.64 \mathrm{a}$ \\
\hline
\end{tabular}

C, carbon; N, nitrogen; EOC, extractable organic C; EON, extractable organic N.

Different letters in the same row indicate significant differences at $P<0.05$ among tree species.

further updated Model 1 to create Model 2, as shown below:

$$
\begin{aligned}
& \mathrm{EEA}_{\mathrm{it}}=\exp \left\{\beta_{0}+\beta_{1} \times T\right. \\
& \left.+\left(X_{1 \mathrm{it}} \times \beta_{2 \mathrm{sp}}+X_{2 \mathrm{it}} \times \beta_{2 \mathrm{hp}}+X_{3 \mathrm{it}} \times \beta_{2 \mathrm{kp}}\right)+\varepsilon_{\mathrm{it}}\right\} .
\end{aligned}
$$

All the parameters in Model 2 have been described in Model 1. We ran all these enzyme activity data in Model 2 and the $F$ test results are shown in Table S3.

A conventional soil enzyme-C model (Model 3) (Schimel and Weintraub, 2003) has been widely used to predict how soil organic $\mathrm{C}$ contents change with soil EEA over time.

$d_{\mathrm{TC}} / d_{t}=-K \times \mathrm{EEA}$

In this study, for quantitative analysis of the changes in soil total C (TC) contents over time under tree species, we combined Model 2 with the addition of TC and Model 3 together to establish a dynamic tree species-enzyme-C model (Model 4) as shown below:

$d_{\mathrm{TC}} / d_{t}=-K \times \mathrm{EEA}$,

where the function of EEA is

$\operatorname{EEA}(T$, Tree, $\mathrm{TC})=\exp \left\{\beta_{0}+\beta_{1} \times T\right.$

$\left.+\left(X_{1 \mathrm{it}} \times \beta_{2 \mathrm{sp}}+X_{2 \mathrm{it}} \times \beta_{2 \mathrm{hp}}+X_{3 \mathrm{it}} \times \beta_{2 \mathrm{kp}}\right)+\beta_{3} \times \mathrm{TC}\right\}$,

with the boundary conditions $t=$ time $=0, \mathrm{TC}=\mathrm{TC}_{0}$, and $\mathrm{TC}>0$.

To get a better understanding these four models, we made a simple table to compare the advantages and disadvantages of each model (Table 2). We further got an analytical solution of a differential equation for Model 4 and the equation (Eq. 5) is shown below:

$$
\begin{aligned}
& \mathrm{TC}=-1 / \beta_{3} \times \log \left\{\beta_{3} \times \exp \left\{\beta_{0}+\beta_{1} \times T\right.\right. \\
& +\left(X_{1 \mathrm{it}} \times \beta_{2 \mathrm{sp}}+X_{2 \mathrm{it}} \times \beta_{2 \mathrm{hp}}+X_{3 \mathrm{it}} \times \beta_{2 \mathrm{kp}}\right) \\
& \left.\left.+\log (K) \times t+\exp \left\{-\beta_{3} \times \mathrm{TC}_{0}\right\}\right\}\right\}
\end{aligned}
$$

where $K$ is the unit conversion coefficient when $t=0$ and $\mathrm{TC}=\mathrm{TC}_{0}$.
Similarly, when we consider the relationship between total soil N (TN) and enzyme activities, we get a similar analytical solution of the differential equation (Eq. 6) as shown below:

$$
\begin{aligned}
& \mathrm{TN}=-1 / \beta_{3} \times \log \left\{\beta_{3} \times \exp \left\{\beta_{0}+\beta_{1} \times T\right.\right. \\
& +\left(X_{1 \mathrm{it}} \times \beta_{2 \mathrm{sp}}+X_{2 \mathrm{it}} \times \beta_{2 \mathrm{hp}}+X_{3 \mathrm{it}} \times \beta_{2 \mathrm{kp}}\right) \\
& \left.\left.+\log (K) \times t+\exp \left\{-\beta_{3} \times \mathrm{TN}_{0}\right\}\right\}\right\},
\end{aligned}
$$

where $K$ is the unit conversion coefficient when $t=0$ and $\mathrm{TN}=\mathrm{TN}_{0}$.

Using Eq. (5), we calculated the total soil C decomposition over time and compared the residual soil $\mathrm{C}$ contents over time among the tree species for different enzyme activities. As the three coniferous tree species showed similar soil C decomposition patterns across time, we only calculated the responses of the residual soil $\mathrm{C}$ contents to different temperatures under slash pine and Eucalyptus. The model parameters of Eq. (5) for different enzyme activities under different tree species are shown in Table S4.

Similarly, using Eq. (6), we calculated the total soil $\mathrm{N}$ decomposition over time and compared the residual soil $\mathrm{N}$ contents among the tree species for different enzyme activities. On the basis of the residual soil $\mathrm{C}$ and $\mathrm{N}$ contents over time, we finally calculated the ratios of the residual soil $\mathrm{C}$ and $\mathrm{N}$ contents among the tree species over time. The model parameters of Eq. (6) for different enzyme activities under different tree species are shown in Table S5.

\section{Results}

Tree species and temperature significantly affected soil BG, NAG, LAP and acid phosphatase $(P<0.05)$ (Table S1). However, there was no significant effect of the interaction between tree species and temperature on the activity of these enzymes. In general, Eucalyptus had 1.01-2.86 times higher soil EEA than the other tree species along a temperature gradient (Fig. 1), followed by native coniferous species (kauri pine and hoop pine), whereas exotic conifer species (slash pine) had the lowest soil enzyme activity, except for NAG enzyme activity (Fig. 1). 
Table 2. Description and comparison of the four models used in this study. EEA, extracellular enzyme activities.

\begin{tabular}{|c|c|c|c|c|}
\hline & Model 1 & Model 2 & Model 3 & Model 4 \\
\hline Advantage & $\begin{array}{l}\text { Tree species-enzyme } \\
\text { model with } \\
\text { considering the effects of } \\
\text { tree species, incubation } \\
\text { temperature and their } \\
\text { interactions on soil EEA }\end{array}$ & $\begin{array}{l}\text { Tree species-enzyme model with } \\
\text { only considering tree species and } \\
\text { incubation temperature on soil } \\
\text { EEA, as their interactions were } \\
\text { not significant in this study (see } \\
\text { Table S1) }\end{array}$ & $\begin{array}{l}\text { Conventional } \\
\text { enzyme-C model }\end{array}$ & $\begin{array}{l}\text { Tree species-enzyme-C } \\
\text { model by combining } \\
\text { Model } 2 \text { and Model } 3\end{array}$ \\
\hline Disadvantage & $\begin{array}{l}\text { Without considering the } \\
\text { interactions of soil EEA }\end{array}$ & $\begin{array}{l}\text { Without considering the interac- } \\
\text { tions of soil EEA }\end{array}$ & $\begin{array}{l}\text { Without considering } \\
\text { the effects of tree } \\
\text { species and without } \\
\text { considering the inter- } \\
\text { actions of soil EEA }\end{array}$ & $\begin{array}{l}\text { Without considering the } \\
\text { interactions of soil EEA }\end{array}$ \\
\hline
\end{tabular}

(a)

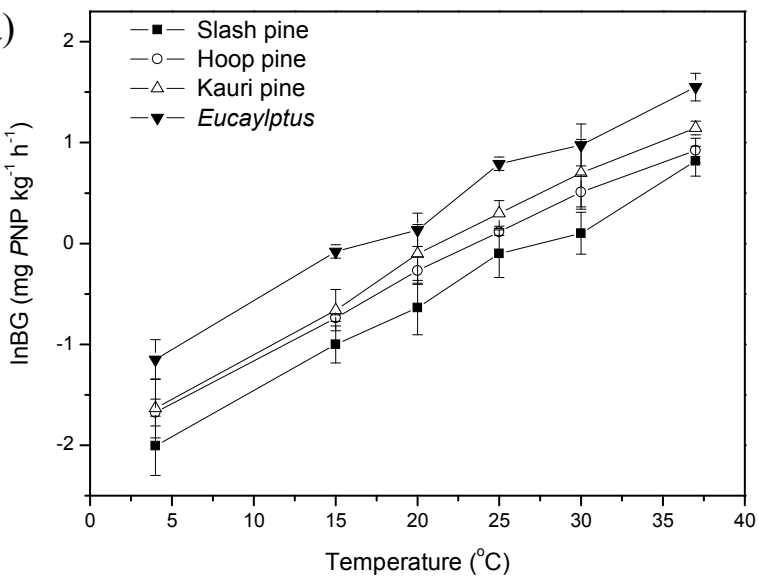

(c)

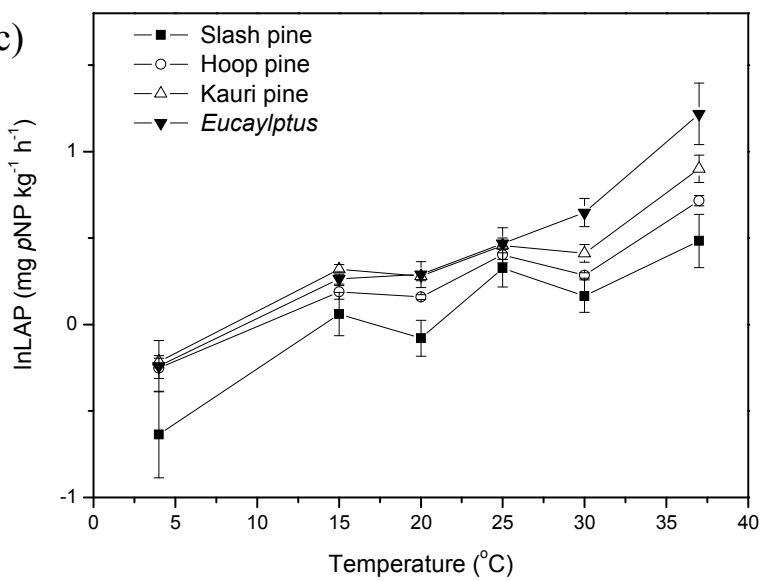

(b)

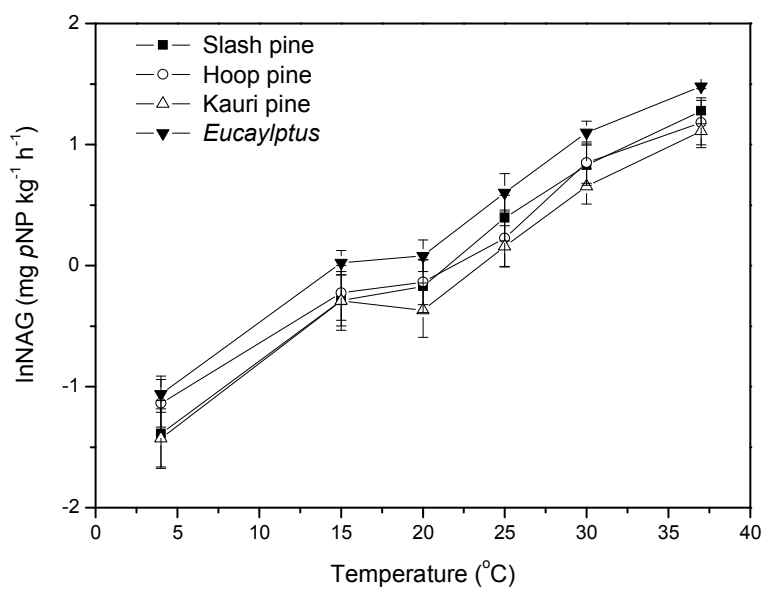

(d)

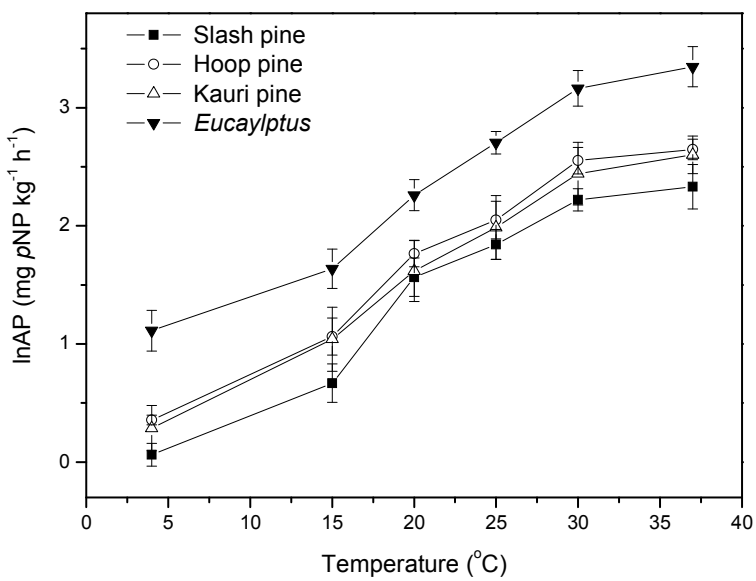

Figure 1. Extracellular enzyme activity in the soil along a gradient of temperatures under different tree species. (a) $\beta$-glucosidase (BG); (b) $N$-acetylglucosaminidase (NAG); (c) leucine aminopeptidase (LAP); (d) acid phosphatase (AP) and $p$ NP, para-nitrophenol. 

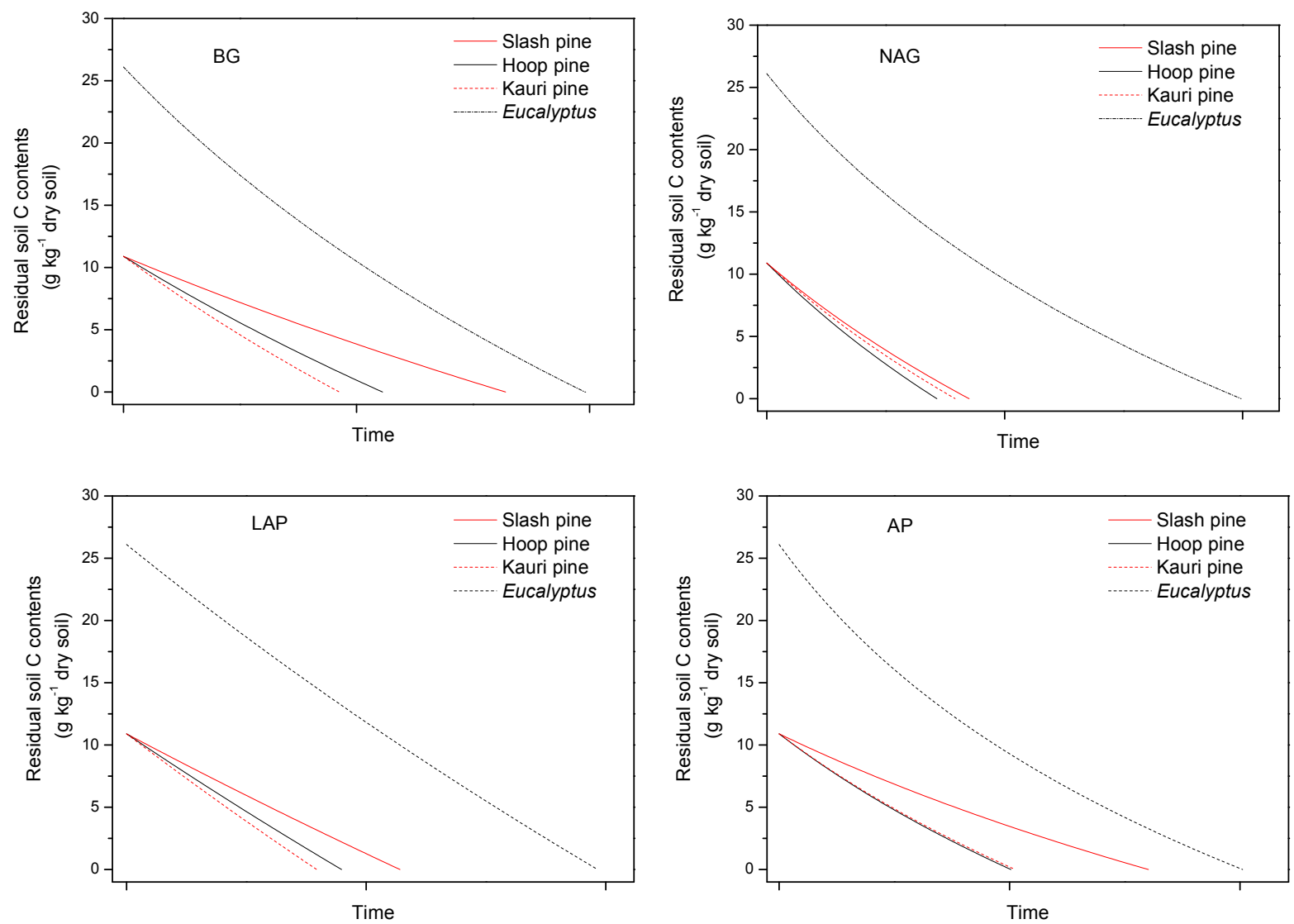

Figure 2. Residual soil $\mathrm{C}$ contents under different tree species across time for $\beta$-glucosidase (BG), $N$-acetylglucosaminidase (NAG), leucine aminopeptidase (LAP) and acid phosphatase (AP) at $25^{\circ} \mathrm{C}$. The total soil $\mathrm{C}$ decomposition over time was calculated via Eq. (5) and the residual soil $\mathrm{C}$ contents over time was compared for different enzyme activities among the tree species.

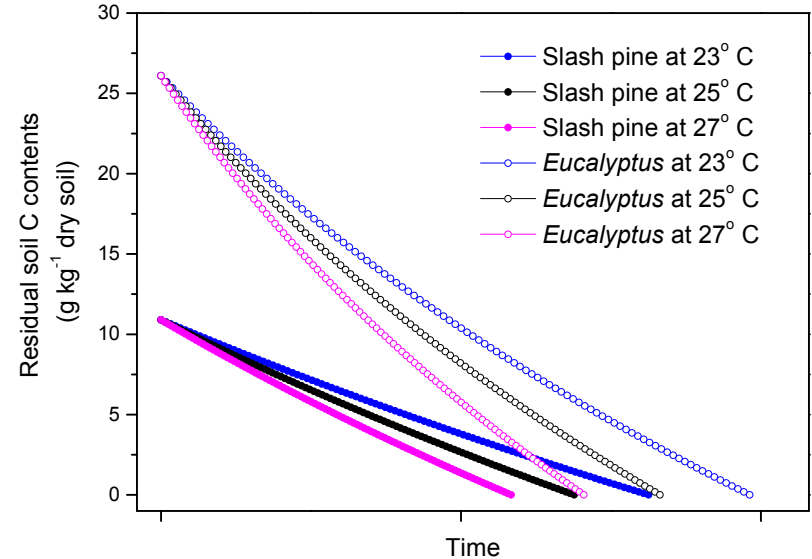

Figure 3. Residual soil $\mathrm{C}$ contents with $\beta$-glucosidase at 23,25 and $27^{\circ} \mathrm{C}$ under slash pine and Eucalyptus over time. The total soil $\mathrm{C}$ decomposition over time was calculated via Eq. (5) and the residual soil $\mathrm{C}$ contents over time was compared for different enzyme activities among the tree species.
The decreasing trends for residual soil $\mathrm{C}$ contents over time under different tree species were similar for all enzyme activities (Fig. 2). In general, Eucalyptus had the highest soil enzyme activity, followed by slash pine, hoop pine and kauri pine. Notably, Eucalyptus had 0.99-1.92 times longer soil C residence time than that of slash pine, 1.56-2.27 times longer than hoop pine, and 1.56-2.38 times longer than kauri pine, respectively; slash pine had 1.06-1.77 times longer soil C residence time than the other two coniferous species (Table S6).

Temperature significantly influenced soil $\mathrm{C}$ decomposition, indicating that slash pine and Eucalyptus had shorter soil $\mathrm{C}$ residence times at higher temperatures than at lower temperatures (Fig. 3). At a given temperature, Eucalyptus had greater soil $\mathrm{C}$ losses but higher remaining soil $\mathrm{C}$ contents than slash pine (Fig. 3). Interestingly, we noticed that for a certain tree species, the gaps between residual soil C contents with BG at 23,25 and $27^{\circ} \mathrm{C}$ increased with time, which may be explained by the canceling effects (absence or strong reduction of response of the enzyme to temperature) of soil EEA (Razavi et al., 2015). Previous findings showed that this phenomenon was most pronounced at low substrate 

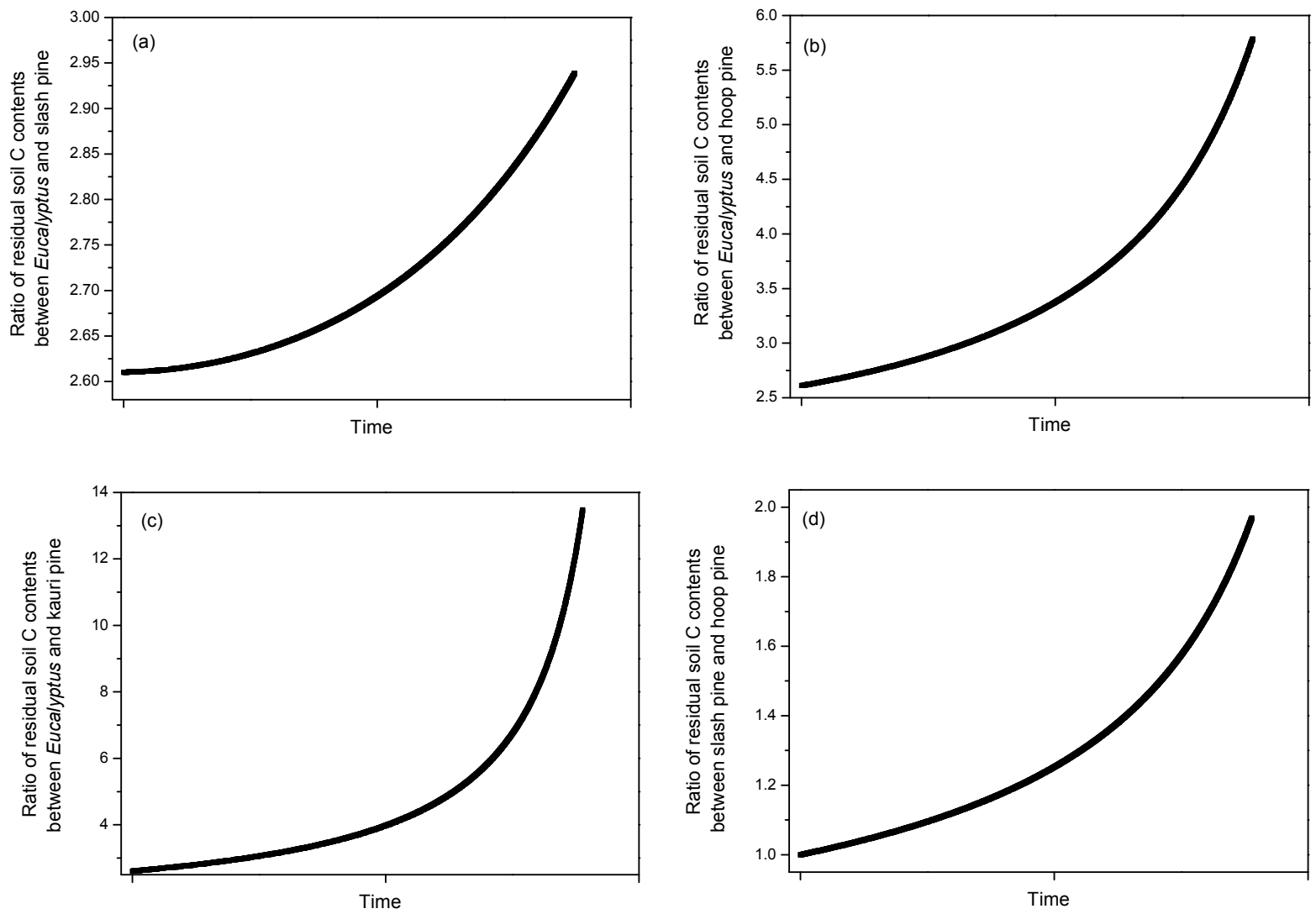

Figure 4. Ratios of residual soil C contents between Eucalyptus and slash pine (a), between Eucalyptus and hoop pine (b), between Eucalyptus and kauri pine (c) and between slash pine and hoop pine (d) for $\beta$-glucosidase across time.

concentrations (Razavi et al., 2015), which was consistent with our results in Fig. 3.

We also calculated the ratios of residual soil $\mathrm{C}$ contents between Eucalyptus and slash pine, between Eucalyptus and hoop pine, between Eucalyptus and kauri pine, and between slash pine and hoop pine. All of them exhibited consistent and similar patterns and increased with time (Fig. 4).

The decreasing trends for soil $\mathrm{N}$ contents under different tree species over time for NAG and LAP showed similar patterns (Fig. 5). Eucalyptus had the highest soil EEA but 1.391.92 times longer decomposition time than that of the other coniferous species. This is because Eucalyptus had a relatively flatter slope across time than the other tree species. For NAG, at a given time, Eucalyptus had the highest residual soil $\mathrm{N}$ contents, followed by (in decreasing order) kauri pine, slash pine and hoop pine. For LAP, at a given time, Eucalyptus had the highest residual soil $\mathrm{N}$ contents, followed by (in decreasing order) slash pine, hoop pine and kauri pine. The ratios of residual soil $\mathrm{N}$ contents between Eucalyptus and slash pine for NAG increased with time; similar patterns of the ratios of residual soil $\mathrm{N}$ contents between Eucalyptus and slash pine over time were seen for LAP (Fig. 6 and Table S7).

\section{Discussion}

In this study we found that long-term forest plantations with different tree species had large differences in the quality of SOM, thus giving significant impacts on soil EEA (Fig. 1, Tables 1 and S1). Eucalyptus had the highest soil EEA, which corresponded to higher soil moisture content and total C and $\mathrm{N}$ contents than the other coniferous species (Tables 1 and S1). Through using the new tree species-enzyme-C/N model, we clearly show the changes in residual soil $\mathrm{C}$ and $\mathrm{N}$ contents with time (Figs. 2 and 5) and differences in soil C and $\mathrm{N}$ residence time (Tables S4 and S5) among different tree species. Soil $\mathrm{C}$ and $\mathrm{N}$ residence time is very important for predicting soil $\mathrm{C}$ and $\mathrm{N}$ dynamics (Wallenstein and Weintraub, 2008), as extracellular enzymes play a critical role in soil organic $\mathrm{C}$ decomposition and $\mathrm{N}$ cycling (Todd-Brown et al., 2013). We acknowledged that the actual measurement of $\mathrm{C}$ decomposition and $\mathrm{C}$ residence time require use of stable isotope techniques. However, our modeling results provide a relative comparison of soil $\mathrm{C}$ and $\mathrm{N}$ residence time among different tree species without units (see Figs. 2 and 5). Moreover, our modeling clearly shows that tree species effects on soil $\mathrm{C}$ cycling are larger than the effects of the future scenario of a temperature increase of $2{ }^{\circ} \mathrm{C}$ (see Fig. S1). 

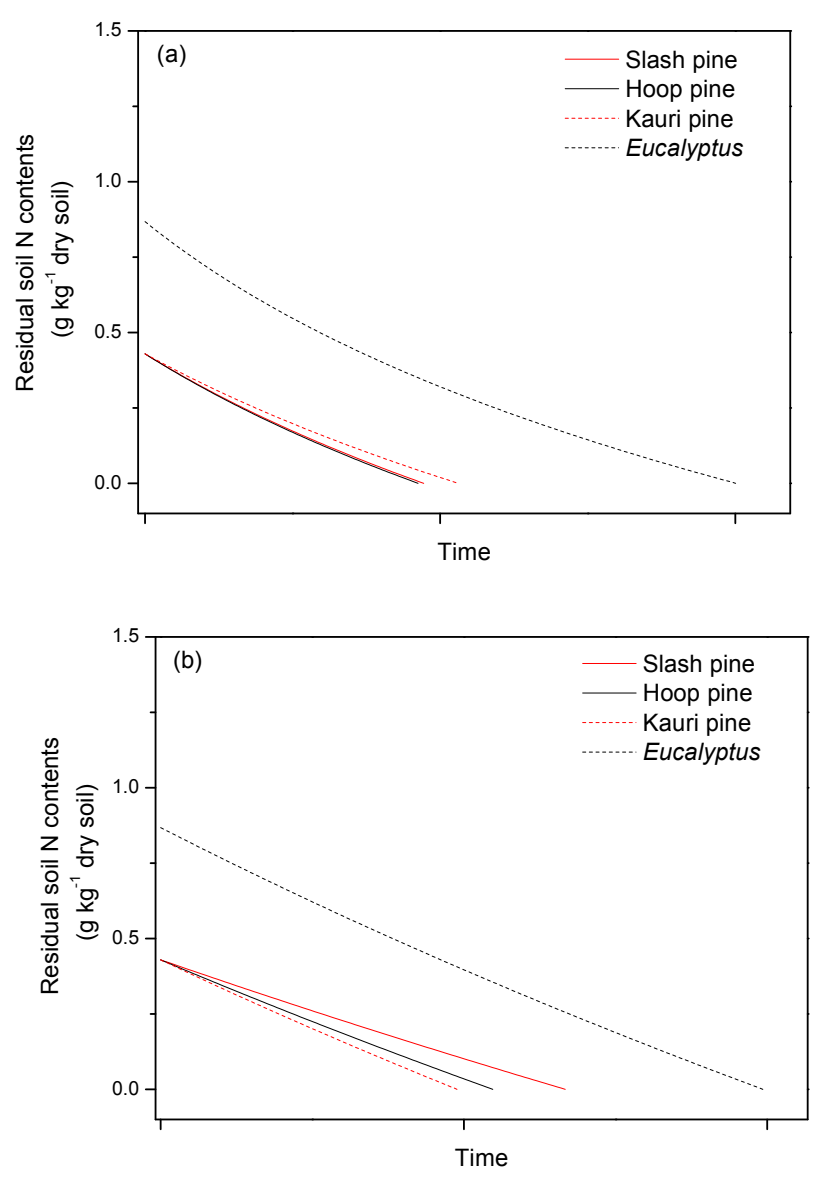

Figure 5. Residual soil $\mathrm{N}$ contents under different tree species with $N$-acetylglucosaminidase (a) and leucine aminopeptidase (b) across time. The total soil $\mathrm{N}$ decomposition over time was calculated via Eq. (6) and the residual soil $\mathrm{N}$ contents over time was compared for different enzyme activities among the tree species.

\subsection{Mechanisms for the differences in soil $\mathrm{C}$ and $\mathrm{N}$ contents between Eucalyptus and coniferous trees}

We modeled the responses of residual soil $\mathrm{C}$ contents to enzyme activity over time (Fig. 2). The results clearly show that Eucalyptus had a longer soil $\mathrm{C}$ residence time and higher turnover rates (see Table S6) for all enzyme activities than coniferous tree species, even though similar patterns can be seen when soil enzyme activities under slash pine and Eucalyptus respond to different temperatures (Fig. 3). The longer soil $\mathrm{C}$ residence time under Eucalyptus could be attributed to (1) higher initial soil C contents (see Fig. 2), which was supported by the higher forest floor C stocks under Eucalyptus than under the other coniferous tree species (Fig. S1), and (2) lower soil $\mathrm{pH}$, which can inhibit soil microbial activity (Lu et al., 2012) and increase the specific acidobacterial group, indicators of soil acidic levels, in soils in this region (Zhou et al., 2017) using high-throughput sequencing. We noticed that there were significantly negative correlations between soil organic $\mathrm{C}$ and soil $\mathrm{pH}(r=-0.58, P<0.001)$.

Eucalyptus had a longer mean soil $\mathrm{N}$ residence time for LAP and higher soil $\mathrm{N}$ turnover rates than the other tree species (Fig. 5 and Table S7). Unlike NAG, which is involved in chitin and fungal cell wall breakdown in the short term, LAP can break down polypeptides in the long term and is involved in the mineralization of $\mathrm{N}$ from the substrates with polypeptides (Sinsabaugh et al., 2002; Weand et al., 2010). The longer mean soil $\mathrm{N}$ residence time could be another reason for the higher soil C contents seen under Eucalyptus, as higher $\mathrm{N}$ contents may support plant growth and, in turn, increase soil C stocks.

\subsection{Mechanisms for differences in soil $\mathrm{C}$ and $\mathrm{N}$ contents between exotic and native pine species}

Exotic coniferous tree species such as slash pine have been widely planted in eastern Australia (Lu et al., 2012). Slash pine has a faster growth rate than the native hoop pine and kauri pine (Maggs, 1985), which was supported by the higher forest floor C stocks (see Fig. S2) and higher soil C stocks (Table 1) under slash pine. Hobbie (2015) synthesized the effects of tree species on soil $\mathrm{N}$ cycling and provided four different mechanisms to explain faster plant growth under different tree species. Here, we reported a mechanism for faster growth rate under slash pine. We found that slash pine had a longer soil $\mathrm{N}$ residence time than the other coniferous tree species (Figs. 2 and 4), indicating that slash pine has higher residual $\mathrm{N}$ contents across time, which may enhance the available $\mathrm{N}$ contents in the soil for tree growth. Previous results have shown that slash pine need lower levels of nutrients (N, P and potassium) for its growth, whereas hoop and kauri pines are $\mathrm{N}$-demanding species and are known to accumulate relatively recalcitrant $\mathrm{N}$ in forest floor materials (Bubb et al., 1998). On the other hand, we noticed that slash pine had lower soil $\mathrm{pH}$, which could inhibit microbial decomposition of SOM (Lu et al., 2012) and thus contribute to the longer soil $\mathrm{C}$ and $\mathrm{N}$ residence time under slash pine than under the other coniferous tree species.

\subsection{Ratios of residual soil $\mathrm{C}$ and $\mathrm{N}$ contents between tree species}

Global C models usually use a specific parameter to describe soil C decomposition (Todd-Brown et al., 2013). Some of them can simulate microbial decomposition through a new soil biogeochemistry model (Davidson et al., 2012; Steinweg et al., 2012; Wieder et al., 2013). However, the mechanisms of the dynamics of soil $\mathrm{C}$ and $\mathrm{N}$ contents under different tree species and the mechanisms of the different decomposition times between sites with different soil fertility levels are still unclear (Hobbie, 2015). Here, we found that the more fertile soil seen under Eucalyptus, which had higher soil $\mathrm{C}$ and $\mathrm{N}$ contents, lost more soil $\mathrm{C}$ and $\mathrm{N}$, as it had higher $\mathrm{C}$ - and 

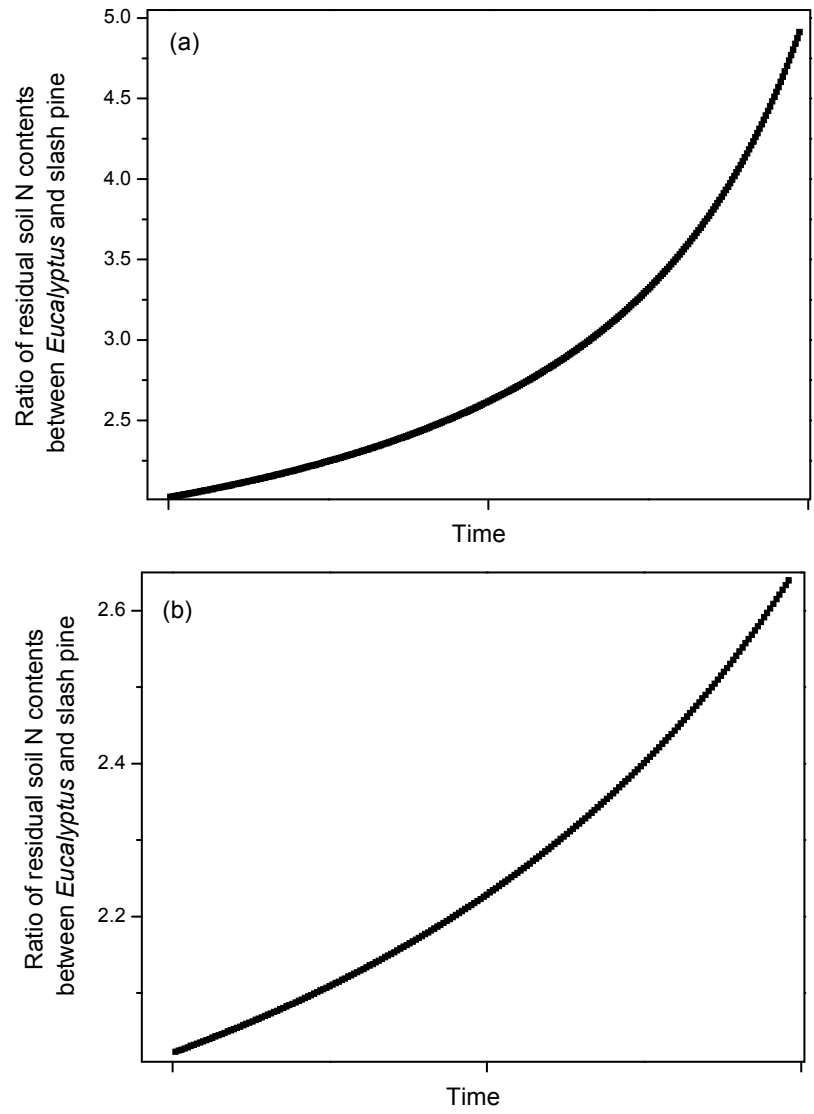

Figure 6. Ratios of residual soil N contents between Eucalyptus and slash pine for $\mathrm{N}$-acetylglucosaminidase (a) and leucine aminopeptidase (b) across time.

N-related enzyme activity. However, as the soil under Eucalyptus had a longer soil $\mathrm{C}$ and $\mathrm{N}$ residence time than the less fertile soil under coniferous tree species with lower soil C and $\mathrm{N}$ contents, the differences in the residual soil $\mathrm{C}$ and $\mathrm{N}$ contents between Eucalyptus and coniferous tree species became larger and larger with time (see Figs. 4 and 6). Similarly, the differences in residual soil $\mathrm{C}$ and $\mathrm{N}$ contents among coniferous tree species became larger and larger with time as well. These results are helpful for understanding soil $\mathrm{C}$ and $\mathrm{N}$ cycling in tree plantations.

\section{Conclusions}

Both tree species and temperature significantly affected soil EEA. Our modeling analysis clearly shows that though Eucalyptus had higher soil EEA activities, it had 0.99-2.38 times longer residual soil $\mathrm{C}$ residence time and 1.39-1.92 times longer residual soil $\mathrm{N}$ residence time, respectively. Furthermore, the differences in soil $\mathrm{C}$ and $\mathrm{N}$ contents between Eucalyptus and coniferous tree species, as well as between slash pine and hoop pine, became larger and larger with decomposition time, which is in contrast to what we expected. On the other hand, our results help to explain why exotic slash pine can grow faster than the other species studied, as it had 1.221.38 times longer residual soil $\mathrm{N}$ residence time for LAP than native coniferous tree species like hoop pine and kauri pine. Soil extracellular enzyme assays in combination with statistical modeling are powerful tools for exploring the mechanisms of soil $\mathrm{C}$ and $\mathrm{N}$ cycling by different tree species. Our results can provide useful information for local forest management.

Data availability. The soil physicochemical properties and soil extracellular enzyme activity data are available upon request to the lead author.

\section{The Supplement related to this article is available online at https://doi.org/10.5194/bg-14-5393-2017-supplement.}

Competing interests. The authors declare that they have no conflict of interest.

Acknowledgements. This study was jointly supported by $\mathrm{Na}-$ tional Natural Science Foundation of China (no. 31600406), East China Normal University (no. 13903-120215-10208 and no. 40500-20101-222011) and Griffith University Postdoctoral Fellowship, Griffith University New Researcher Funding. S. Wang acknowledges the support of the Australian Research Council (DP 150103710).

Edited by: Yakov Kuzyakov

Reviewed by: three anonymous referees

\section{References}

Allison, S. D.: Cheaters, diffusion and nutrients constrain decomposition by microbial enzymes in spatially structured environments, Ecol. Lett., 8, 626-635, 2005.

Allison, S. D., Wallenstein, M. D., and Bradford, M. A.: Soil-carbon response to warming dependent on microbial physiology, Nat. Geosci., 3, 336-340, 2010.

Bengtson, P. and Bengtsson, G.: Rapid turnover of DOC in temperate forests accounts for increased $\mathrm{CO}_{2}$ production at elevated temperatures, Ecol. Lett., 10, 783-790, 2007.

Berthrong, S. T., Lobbagy, E. G., and Jackson, R. B.: A global metaanalysis of soil exchangable cations, $\mathrm{pH}$, carbon, and nitrogen with afforestation, Ecol. Appl., 19, 2228-2241, 2009.

Bubb, K. A., Xu, Z. H., Simpson, J. A., and Saffigna, P. G.: Some nutrient dynamics associated with litterfall and litter decomposition in hoop pine plantations of southeast Queensland, Australia, Forest Ecol. Manag., 110, 343-352, 1998.

Caldwell, B. A.: Enzyme activities as a component of soil biodiversity: a review, Pedobiologia, 49, 637-644, 2005. 
Conant, R. T., Ryan, M. G., Ågren G. I., Birge, H. E., Davidson, E. A., Eliasson, P. E., Evans, S. E., Frey, S. D., Giardina, C. P., Hopkins, F. M., Hyvonen, R., Kirschbaum, M. U. F., Lavallee, J. M., Leifeld, J., Parton, W. J., Steinweg, J. M., Wallenstein, M. D., Wetterstedt, J. A. M., and Bradford, M. A.: Temperature and soil organic matter decomposition rates - synthesis of current knowledge and a way forward, Glob. Change Biol., 17, 3392-3404, 2011.

Davidson, E. A. and Janssens, I.: Temperature sensitivity of soil carbon decomposition and feedbacks to climate change, Nature, 440, 165-173, 2006.

Davidson, E. A., Samanta, S., Caramori, S. S., and Savage, K.: The dual Arrhenius and Michaelis-Menten kinetics model for decomposition of soil organic matter at hourly to seasonal time scales, Glob. Change Biol., 18, 371-384, 2012.

Hobbie, S. E.: Plant species effects on nutrient cycling: revisiting litter feedbacks, Trends Ecol. Evol., 30, 357-363, 2015.

IPCC 2013: The physical science basis, Contribution of Working Group I to the Fifth Assessment Report of the Intergovernmental Panel on Climate Change, Cambridge University Press, Cambridge, UK, 2013.

Jobbágy, E. G. and Jackson, R. B.: The vertical distribution of soil organic carbon and its relation to climate and vegetation, Ecol. Appl., 10, 423-436, 2000.

Kardol, P., Cregger, M. A., Campany, C. E., Classen, A. T.: Soil ecosystem functioning under climate change: plant species and community effects, Ecology, 91, 767-781, 2010.

Koch, O., Tscherko, D., and Kandeler, E.: Temperature sensitivity of microbial respiration, nitrogen mineralization, and potential soil enzyme activities in organic alpine soils, Global Biogeochem. Cy., 21, GB4017, https://doi.org/10.1029/2007GB002983, 2007.

Lawrence, C. R., Neff, J. C., and Schimel, J. P.: Does adding microbial mechanisms of decomposition improve soil organic matter models? A comparison of four models using data from a pulsed rewetting experiment, Soil Biol. Biochem., 41, 19231934, 2009.

Li, X., Miller, A. E., Meixner, T., Schimel, J. P., Melack, J. M., and Sickman, J. O.: Adding an empirical factor to better represent the rewetting pulse mechanism in a soil biogeochemical model, Geoderma, 159, 440-451, 2010.

Lovett, G. M., Weathers, K. C., Arthur, M. A., and Schultz, J. C.: Nitrogen cycling in a northern hardwood forest: do species matter?, Biogeochemistry, 67, 289-308, 2004.

Lu, S. B., Chen, C. R., Zhou, X. Q., Xu, Z. H., Bacon, G., Rui, Y. C., and Guo, X. M.: Respones of soil dissolved organic matter to long-term plantations of three coniferous tree species, Geoderma, 170, 136-143, 2012.

Luo, Y. Q.: Terrestrial carbon cycle feedback to climate warming, Annu. Rev. Ecol. Evol. S., 36, 683-712, 2007.

Maggs, J.: Litter fall and re-translocation of nutrients in refertilized and prescribed burned Pinus elliottii plantation, Forest Ecol. Manag., 12, 253-268, 1985.
Razavi, B. S., Blagodatskaya, E., and Kuzyakov, Y.: Nonlinear temperature sensitivity of enzyme kinetics explains cancelling effects - a case study on loamy haplic Lusivol, Front. Microbiol., 6, 1126, https://doi.org/10.3389/fmicb.2015.01126, 2015.

Schimel, J. P. and Bennett, J.: Nitrogen mineralization: challenges of a changing paradigm, Ecology, 85, 591-602, 2004.

Shimel, J. P. and Weintraub, M. N.: The implication of exoenzyme activity on microbial carbon and nitrogen limitation in soil: a theoretical model, Soil Biol. Biochem., 35, 549-563, 2003.

Sinsabaugh, R. L., Carreiro, M. M., and Repert, D. A.: Allocation of extracellular enzymatic activity in relation to litter composition, $\mathrm{N}$ deposition, and mass loss, Biogeochemistry, 60, 1-24, 2002.

Sinsabaugh, R. L., Hill, B. H., and Shah, J. J. F.: Ecoenzymatic stoichiometry of microbial organic nutrient acquisition in soil and sediment, Nature, 462, 795-798, 2009.

Steinweg, J. M., Dukes, J. S., and Wallenstein, M. D.: Modeling the effects of temperature and moisture on soil enzyme activity: linking laboratory assays to continuous field data, Soil Biol. Biochem., 55, 85-92, 2012.

Todd-Brown, K. E. O., Randerson, J. T., Post, W. M., Hoffman, F. M., Tarnocai, C., Schuur, E. A. G., and Allison, S. D.: Causes of variation in soil carbon simulations from CMIP5 Earth system models and comparison with observations, Biogeosciences, 10, 1717-1736, https://doi.org/10.5194/bg-10-1717-2013, 2013.

Verchot, L. V. and Borelli, T.: Application of para-nitrophenol $(p N \mathrm{~N})$ enzyme assays in degraded tropical soils, Soil Biol. Biochem., 37, 625-633, 2005.

Vesterdal, L., Clarke, N., Sigurdsson, B. D., and Gundersen, P.: Do tree species influence soil carbon stocks in temperate and boreal forests?, Forest Ecol. Manag., 309, 4-18, 2013.

Wallenstein, M. D. and Weintraub, M. N.: Emerging tools for measuring and modeling the in situ activity of soil extracellular enzymes, Soil Biol. Biochem., 40, 2098-2106, 2008.

Weand, M. P., Arthur, M. A., Lovett, G. M., McCulley, R. L., and Weathers, K. C.: Effects of tree species and $\mathrm{N}$ additions on forest floor microbial communities and extracellular enzyme activities, Soil Biol. Biochem., 42, 2161-2173, 2010.

Wieder, W. R., Bonan, G. B., and Allison, S. D.: Global soil carbon projections are improved by modelling microbial processes, Nat. Clim. Change, 3, 909-912, 2013.

Wu, Z. T., Dijkstra, P., Koch, G. W., Peñuelas J., and Hungate, B. A.: Response of terrestrial ecosystems to temperature and precipitation change: a meta-analysis of experimental manipulation, Glob. Change Biol., 17, 927-942, 2011.

Zhou, X. Q., Chen, C. R., Wang, Y. F., Xu, Z. H., Han, H. Y., Li, L. H., and Wan, S. Q.: Warming and increased precipitation have differential effects on soil extracellular enzyme activities in a temperate grassland, Sci. Total Environ., 444, 552-558, 2013.

Zhou, X., Guo, Z., Chen, C., and Jia, Z.: Soil microbial community structure and diversity are largely influenced by soil $\mathrm{pH}$ and nutrient quality in 78 year-old tree plantations, Biogeosciences, 14, 2101-2111, https://doi.org/10.5194/bg-14-2101-2017, 2017. 